\title{
Monoicy in $A$. angustifolia (Bert.) O. Kuntze (Araucariaceae): I. Morphological aspects of the reproductive structures*
}

\author{
VALDIR M. STEFENON ${ }^{1}$ and CLARISSA A. CAPRESTANO ${ }^{2}$ \\ ${ }^{1}$ Universidade Federal do Pampa, Campus São Gabriel, Av. Antonio Trilha, 1847, 97300-000 São Gabriel, RS, Brasil \\ ${ }^{2}$ Universidade Federal de Santa Catarina, Centro de Ciências Agrárias \\ Laboratório de Fisiologia do Desenvolvimento e Genética Vegetal, Rod. Admar Gonzaga, 1406 \\ Itacorubi, 88040-900 Florianópolis, SC, Brasil \\ Manuscript received on August 4, 2008; accepted for publication on June 4, 2009; \\ presented by LUIZ R. TRAVASSOS
}

\begin{abstract}
Araucaria angustifolia (Bert.) O. Kuntze is a dioecious conifer species native of Brazil. The rare occurrence of monoiceous specimens have been attributed to pathogenic infections or other injuries in adult trees. Here, the morphological characteristics of male and female cones and pollen grains of a monoiceous A. angustifolia are described. Male and female cones and pollen grains presented normal morphology, lacking any sort of injuries or infection and suggesting the existence of further grounds for the occurrence of monoicy in this conifer species.
\end{abstract}

Key words: Araucaria, sexual system, Brazilian pine.

\section{INTRODUCTION}

The genus Araucaria de Jussieu (Araucariaceae) includes 19 species with current geographic distribution restricted to the Southern hemisphere (Golte 1993). Araucaria angustifolia (Bert.) O. Kuntze is the only representative of family Araucariaceae in Brazil and together with its closely related species A. araucana (Setoguchi et al. 1998, Stefenon et al. 2006), the only extant representative of the family in the American continent. Based on ripening time and seed color, ten botanical varieties of $A$. angustifolia are described: 1) elegans; 2) sancti josephi; 3) angustifolia; 4) caiova; 5) indehiscens; 6) nigra; 7) striata; 8) semi-alba; 9) alba (Reitz and Klein 1966) and 10) catarinensis (Matos 1994).

Araucaria angustifolia is a long-lived conifer species with gravity-dispersed seeds (barochory) and wind-

\footnotetext{
*This study was performed during a post-doctoral training of the first author at the Universidade Federal de Santa Catarina.

Correspondence to: Valdir M. Stefenon

E-mail: valdirstefenon@unipampa.edu.br
}

dispersed pollen (anemophily). Alternatively, seeds may be dispersed by vertebrates. However, the transported seeds are often damaged by these animals and not able to germinate (Müller and Macedo 1980, Mello Filho et al. 1981). The pollination occurs between September and October, and seed ripening occurs from March to July. The reproductive cycle of A. angustifolia takes, in general, around two years from the beginning of the female cone development until seed dispersion (Sousa and Hattemer 2003, Mantovani et al. 2004).

Aracaria angustifolia is a mainly dioecious species, but monoiceous specimens are seldom found in nature. The occurrence of monoicy in A. angustifolia has been suggested to occur as an effect of pathogenic infections or other sort of injuries in the adult plant (Reitz and Klein 1966). Up to now, no other physiological or functional explanation has been proposed for the occurrence of this phenomenon. The present note describes the morphological characterization of male and female reproductive structures of a monoiceous specimen of $A$. 
angustifolia found in its natural area of occurrence, in Santa Catarina State, Brazil. The general structure of pollen grains was also studied and compared to the one of pollen grains of dioecious specimens of A. angustifolia described in the literature.

\section{MATERIALS AND METHODS}

The studied plant material was collected in the municipality of Lages, state of Santa Catarina, southern Brazil $\left(27^{\circ} 49^{\prime} 59^{\prime \prime} \mathrm{S}\right.$ and $\left.50^{\circ} 20^{\prime} 49^{\prime \prime} \mathrm{W}\right)$. The collection occurred at October, $9^{\text {th }} 2008$. The tree is around 40 years old and is cultivated in a domestic backyard. A branch with male and female cones (Fig. 1) was collected and the voucher specimen was housed at the Herbarium Flor of the Federal University of Santa Catarina, Florianópolis, Santa Catarina, Brazil, under the register number Flor-37053. Pictures were captured in the Laboratory of Developmental Plant Physiology and Plant Genetics of the Federal University of Santa Catarina using a stereomicroscope Olympus SZH10 or a digital camera Panasonic LZ3. For Scanning Electron Microscopy (SEM), naturally dehydrated pollen grains were coated with gold-palladium and analyzed using a Jeol JSM-6390LV microscope at the Central Laboratory of Electronic Microscopy of the Federal University of Santa Catarina.

\section{RESULTS AND DISCUSSION}

The occurrence of monoicy in A. angustifolia was firstly documented by Reitz and Klein (1966) and to our knowledge no further reports on this topic were published. Monoicy can be expressed in A. angustifolia in three different forms: (i) trees that produced exclusively female (or male) cones during a certain period of time and then started to produce just male (or female) ones; (ii) trees that produce just female cones some years and both male and female cones in the others; and (iii) trees producing both kinds of cones, simultaneously in the same tree (Reitz and Klein 1966). The holotypus described by these authors (collected in September 1962) represented the latter class of monoicy. The other two categories of monoicy were just reported as personal communications to these researchers. Despite the absence of studies on this topic, pathogenic infections or injuries are considered the reason of the monoicy in A. angustifolia (Reitz and Klein 1966).

\section{General Morphology}

In contrast to the hypothesis of pathogenic infections or physical damages as grounds for the monoicy in Araucaria angustifolia, the specimen described here presented healthy appearance, suggesting other physiological cause for this event. The tree produced both male and female cones in the same branch (Fig. 1). As a rule, male and female cones were observed in the same branch, but not in the same ramifications of the branch. Evidences of active production of reproductive structures are given by the presence of immature male and female cones (Figs. 2 and 3 ), in addition to the mature male cones and the developing female cones observed.

\section{Male Structures And Pollen Morphology}

The mature male cones (Figs. 1 and 2) presented a typical form: they were cylindrical, brown-colored, slightly curved and large, reaching about $15 \mathrm{~cm}$ long. The microsporophylls were densely and spirally disposed in the axis of the cone. The monoiceous specimen of A. angustifolia infected with the fungus Uleiella paradoxa Schroet. (Uredinales) described by Reitz and Klein (1966) presented wounded pollen grains and abnormally ramified male cones. The fungus infection was considered by the authors as the cause of the monoicy of the tree.

Like the cones, microsporophylls of the specimen described here presented normal morphology, comprising eight microsporangia (Figs. 7 and 8) and producing a huge amount of pollen. Pollen grains are large in comparison to other conifer species (the average from 50 observations was around $50 \mu \mathrm{m}$; Figs. 9 and 10), sphereshaped and lack structures to assist the fly, as described by Sousa and Hattemer (2003). The pollen grains have a granulated surface formed by irregularly dispersed granules of the exine (Fig. 11). Equivalent characteristics were described by Del Fueyo et al. (2008) for pollen grains of dioecious specimens of $A$. angustifolia.

\section{Female Structures and Pollination}

The older female cone studied produced seeds (Fig. 4), which were already pollinated, but not yet fertilized, since the fertilization of the female gamete occurs around one year after the pollination (Mantovani et al. 2004). In this monoiceous specimen, seed ripening and fall occur 

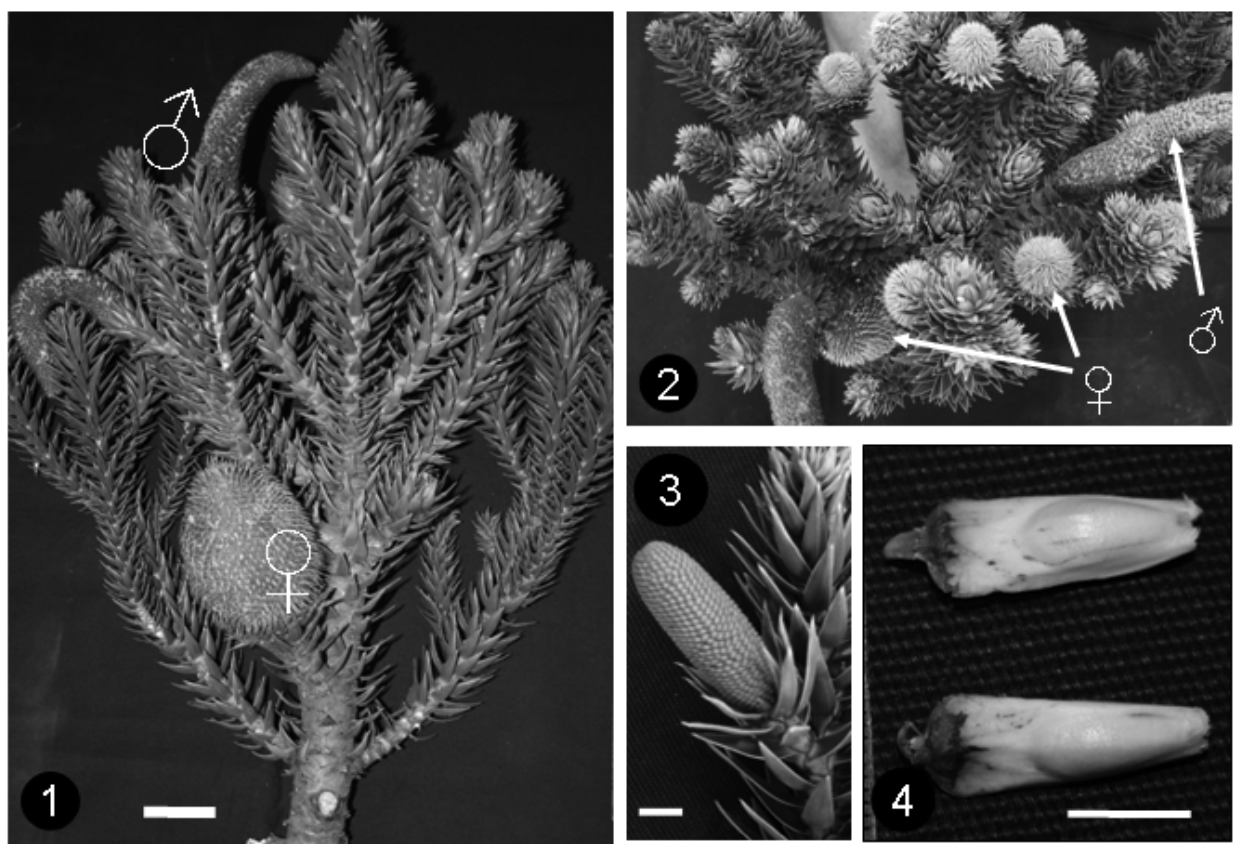

Fig. 1 - Branch showing male and female cones. Note the normal morphological appearance of the reproductive structures. Scale bar $=10 \mathrm{~cm}$. Fig. 2 - Mature male cones and immature female ones, which will maturate in about 18 months. Fig. 3 - Young male cone. Scale bar $=1 \mathrm{~cm}$. Fig. $4-$ Seeds of the older female cone present in the collected branch. Scale bar $=1 \mathrm{~cm}$.
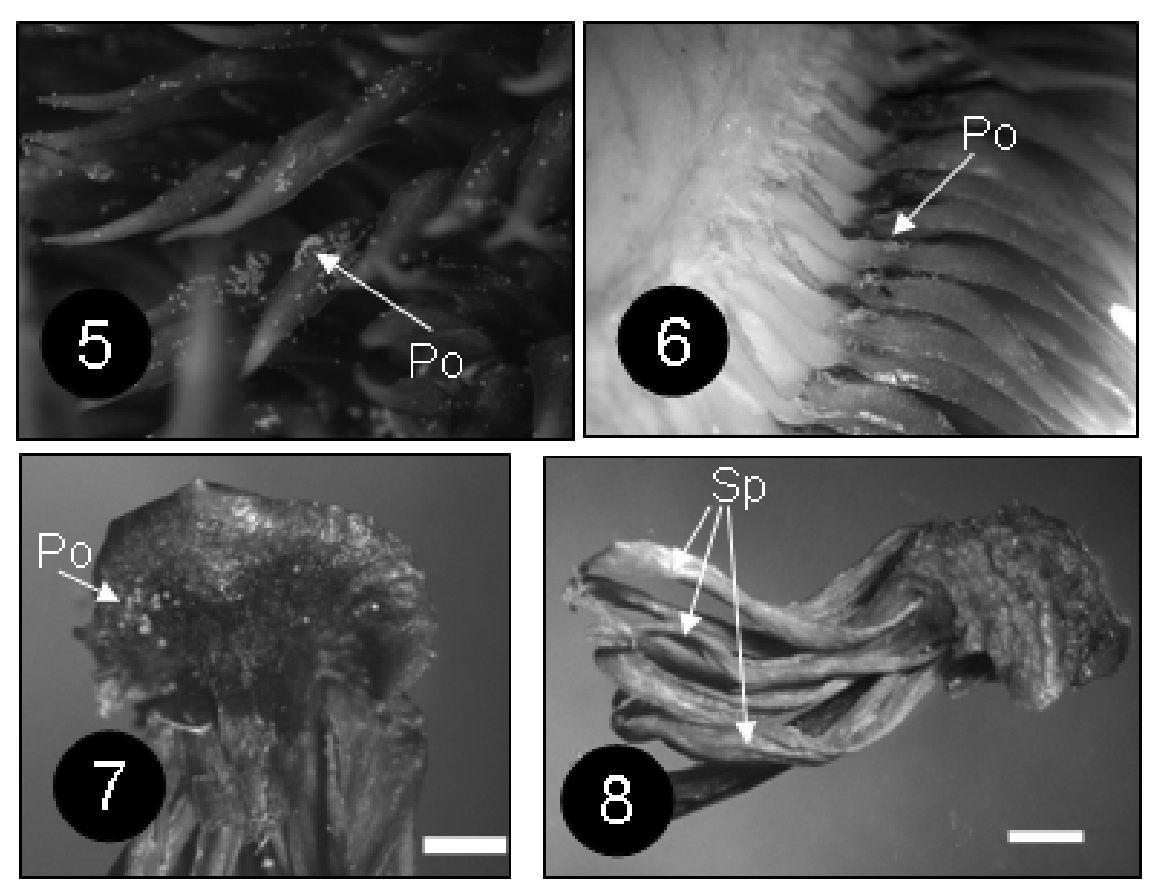

Fig. 5 - Pollen (Po) adhered to megasporophils of an immature female cone. Fig. 6 - Detail of the internal portion of the female cone with pollen grains adhered. Fig. 7 - Detail of the posterior portion of the microsporophil with pollen grains adhered. Scale bar $=0.1 \mathrm{~cm}$. Fig. 8 - Microsporophils with eight sporangia $(\mathrm{Sp})$ in adaxial view. Scale bar $=0.1 \mathrm{~cm}$. 

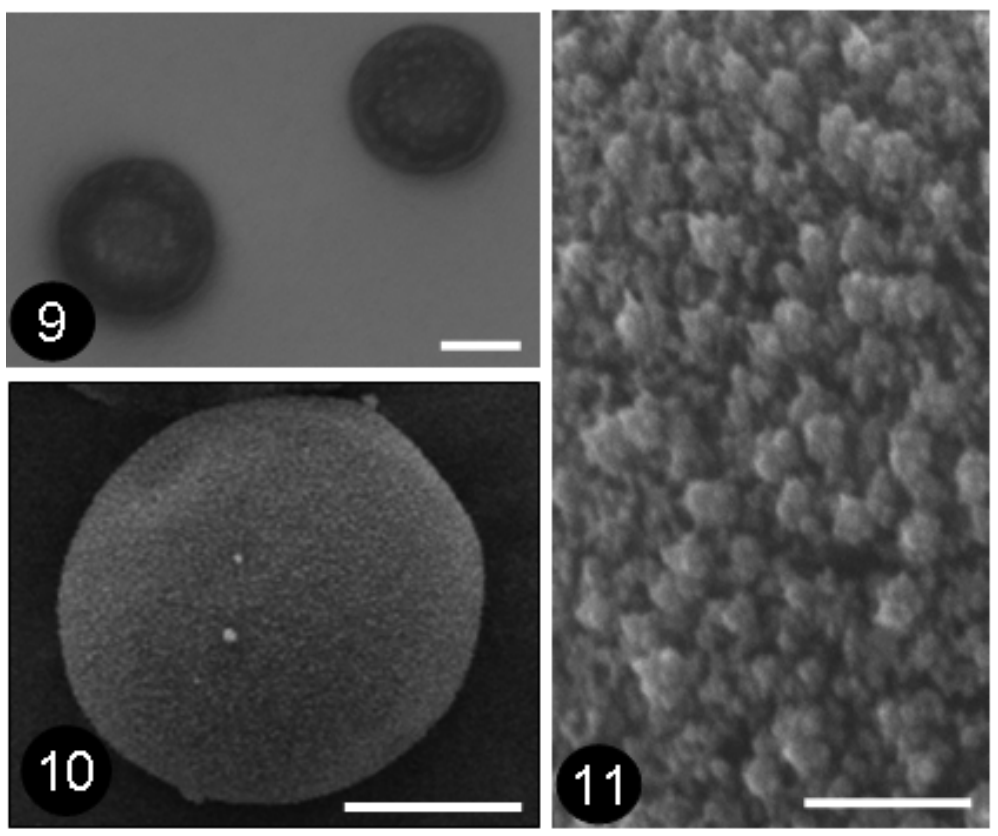

Fig. 9 - Pollen grain visualized under stereomicroscope magnified $100 \times$. Scale bar $=25 \mu \mathrm{m}$. Fig. $10-$ Pollen grain visualized through SEM magnified $400 \times$. Scale bar $=25 \mu \mathrm{m}$. Fig. $11-$ Detail of the pollen grain surface (exine) visualized through SEM magnified $8000 \times$. Scale bar $=2 \mu \mathrm{m}$.

between March and June. Also younger female cones analyzed were already pollinated (Figs. 5 and 6). The monoiceous specimen studied dispersed its pollen from August to September 2008. As a result of the large area of distribution, it is expected that the reproductive phenology of $A$. angustifolia differs among regions of occurrence. In Brazil, pollination of $A$. angustifolia has been reported to occur from August to mid-November (Sousa and Hattemer 2003, Mantovani et al. 2004, Anselmini et al. 2006).

Considering the position of the male cones above the female ones (Fig. 2), the occurrence of self-pollination is a liable event. Pollen grains of A. angustifolia lack a device to enhance its fly and have a relatively low floating rate (from 12.02 to $19.89 \mathrm{~cm} . \mathrm{s}^{-1}$ ) when compared with other tree species (Sousa and Hattemer 2003). These features limiting distance of pollen dispersion increase the probability of auto-pollination in this monoiceous specimen.

\section{CONCLUSIONS AND FurTher Studies}

Since no damages or infections were observed in this tree or in its reproductive structures, new hypotheses have to be tested in order to highlight possible physiological aspects related with the monoicy of this specimen. An ongoing study will characterize the reproductive phenology of this tree, as well as potential physiological features linked to its monoicy. Additionally, tests for auto-pollination using molecular markers will be performed after seeds' fertilization and will be reported in an upcoming paper.

\section{ACKNOWLEDGMENTS}

We would like to thank Mrs. Mirialva L. Soares for permitting the sampling of plant material in her backyard and M.Sc. Diogo Klock Ferreira for helping to prepare the voucher specimen. Prof. Dr. Marisa Santos (CCB/UFSC) kindly provided the pollen grain images.

\section{RESUMO}

Araucaria angustifolia (Bert.) O. Kuntze é uma conífera primariamente dióica nativa do Brasil. A ocorrência de raros exemplares monóicos tem sido creditada a infecções patogênicas ou outras injúrias em árvores adultas. Neste trabalho, as características morfológicas de cones masculinos e femininos 
e dos grãos de pólen de uma $A$. angustifolia monóica são descritas. Os cones masculinos e femininos e os grãos de pólen apresentaram morfologia normal, sem a presença de qualquer tipo de injuria ou infecção, sugerindo a existência de outros mecanismos para a ocorrência de monoicia nesta conífera.

Palavras-chave: Araucaria, sistema sexual, pinheiro brasileiro.

\section{REFERENCES}

Anselmini Ji, Zanette F And Bona C. 2006. Fenologia Reprodutiva da Araucaria angustifolia (BERT.) O. KTZE, na região de Curitiba-PR. Floresta e Ambiente 13: 44-52.

Del Fueyo GM, CACCAVARI MA AND Dome EA. 2008. Morphology and structure of the pollen cone and pollen grain of the Araucaria species from Argentina. Biocell 32: 49-60.

Golte W. 1993. Araucaria: Verbreitung und Standortansprüche einer Coniferengattung in vergleichender Sicht. Franz Steiner, Stuttgart, 167 p.

Mantovani A, Morellato APC And Reis MS. 2004. Fenologia reprodutiva e produção de sementes em Araucaria angustifolia (Bert.) O. Kuntze. Rev Bras Bot 27: 787-796.
MATOS JR. 1994. O pinheiro brasileiro. v. 1, Lages: Artes Gráficas Princesa, 225 p.

Mello Filho JA, Stoehr GWD And Faber J. 1981. Determinação dos danos causados pela fauna a sementes e mudas de Araucaria angustifolia (Bert.) O. Kuntze nos processos de regeneração natural e artificial. Floresta 12: 26-43.

MÜLler JA AND MACEDo JHP. 1980. Notas preliminaries sobre danos causados por animais silvestres em pinhões. Floresta 11: 35-41.

ReITZ PR AND KLEIN RM. 1966. Araucariaceae: Flora ilustrada catarinense. Itajaí: Herbário Barbosa Rodrigues, p. $21-24$.

Setoguchi H, Osawa TA, Pintaud J-C, Jaffré T AND VEILlon J-M. 1998. Phylogenetic relationships within Araucariaceae based on $r b c L$ gene sequences. Am J Bot 85: $1507-1516$.

Sousa VA And Hattemer HH. 2003. Pollen dispersal and gene flow by pollen in Araucaria angustifolia. Aust J Bot 51: 309-317.

Stefenon VM, Gailing O AND Finkeldey R. 2006. Phylogenetic relationship within genus Araucaria (Araucariaceae) assessed by means of AFLP fingerprints. Silvae Genet 55: 45-52. 